\title{
CORRELATION PROFILES OF THE ACCUMULATED METALS IN SEAWATER, SEDIMENT AND Pachygrapsus marmoratus (Fabricius) TISSUES IN BLACK SEA (ORDU, TURKEY)
}

\author{
Şeyda FİKİRDEŞİCİ ERGEN ${ }^{1 *}$, Ahmet ALTINDAĞ ${ }^{1}$, Kuddusi KARABODUK $^{2}$, Levent BİLER ${ }^{1}$, \\ Evren TUNCA ${ }^{3}$
}

${ }^{1}$ Department of Biology, Faculty of Science, Ankara University, Ankara, TURKEY

${ }^{2}$ Gazi University Life Sciences Research and Application Center, Ankara, TURKEY

${ }^{3}$ Ordu University Marine Science and Technology Engineering, Ordu, TURKEY

*Corresponding author: ORCID ID: orcid.org/0000-0002-4623-1256, e-mail: seydafikirdesici@ gmail.com

Cite this article as:

Fikirdeşici Ergen Ş., Altındă̆ A., Karaboduk K., Biler L., Tunca E. 2018. Correlation Profiles of the Accumulated Metals in Seawater, Sediment and Pachygrapsus marmoratus (Fabricius) Tissues in Black Sea (Ordu, Turkey). Trakya Univ J Nat Sci, 19(2): 187-195, DOI: 10.23902/trkjnat.446927

Received: 23 July 2018, Accepted: 14 October 2018, Published: 15 October 2018

\begin{abstract}
This study was performed in order to investigate the interactions of accumulation patterns of some metals (Al, As, Cd, $\mathrm{Cr}, \mathrm{Cu}, \mathrm{Fe}, \mathrm{Mn}, \mathrm{Ni}, \mathrm{Pb}$ and $\mathrm{Zn}$ ) in exoskeleton, gill, hepatopancreas and muscle tissues of the marbled crab Pachygrapsus marmoratus (Fabricius) sampled from near streams and domestic discharge points along the coastal region of Black Sea along Ordu in Turkey as well as patterns in sediment and seawater samples of the crab sampling sites. The study area covering a coastal stretch of $28 \mathrm{~km}$ along Black Sea lies between the latitudes $41^{\circ} 03^{\prime} 46.42^{\prime \prime}-41^{\circ} 07^{\prime} 42.35^{\prime \prime} \mathrm{N}$ and longitudes $37^{\circ} 28^{\prime} 45.63^{\prime \prime}-37^{\circ} 41^{\prime} 15.29^{\prime \prime} \mathrm{E}$. The metal contents of the samples were analysed by the inductively coupled plasma - optical emission spectrometry (ICP-OES) technique. The results showed that the accumulation orders of the metals, in a descending order, were $\mathrm{Fe}>\mathrm{Al}>\mathrm{Mn}>\mathrm{Zn}>\mathrm{Cr}>\mathrm{Pb}>\mathrm{Cu}>\mathrm{As}>\mathrm{Ni}>\mathrm{Cd}$ in the sediment, $\mathrm{Fe}>\mathrm{Mn}>\mathrm{Cr}>\mathrm{As}>\mathrm{Cd}$ in the water, and $\mathrm{Al}>\mathrm{Fe}>\mathrm{Cu}>\mathrm{Mn}>\mathrm{Zn}$ in crab tissues when evaluated together. In the crab samples, the amount of the accumulation of all metals was ordered as gills>exoskeleton>hepatopancreas>muscle. $\mathrm{Al}$ and $\mathrm{Fe}$ were the predominant metals in the sediment and crab tissues but $\mathrm{Al}$ was not detected in the seawater samples. A correlation test was performed to reveal the interaction of accumulation in the sediment, water and crab tissues. Metal-metal interactions and their co-accumulation was detected by correlation test. These interactions which exist in the crab tissues but not in the seawater and sediment were the main point of this study. Gills and exoskeleton displayed the greatest number of significant correlations between metal-metal interactions. Also, metal concentrations were found to be higher in the gills and exoskeleton. Strong correlations between $\mathrm{Mn}-\mathrm{Al}(\mathrm{r}=0.954$, correlation $\mathrm{p}<0.001)$, in the exoskeleton, $\mathrm{Al}-\mathrm{Fe}(\mathrm{r}=0.849$, correlation $\mathrm{p}<0.001), \mathrm{Mn}-\mathrm{Zn}(\mathrm{r}=0.854$, correlation $\mathrm{p}<0.001)$ in the gills, $\mathrm{Al}-\mathrm{Zn}(\mathrm{r}=0.882$ correlation $\mathrm{p}<0.001)$ in the hepatopancreas were determined. Moderate correlations between $\mathrm{Zn}$ - $\mathrm{Cu}$ were found in the hepatopancreas. These metal-metal interactions may have been a result of metallothionein activity. No significant relations were found between metal levels in sediment samples and crap tissues ( $p>0.05$ ). The results also showed that metals present in the seawater and sediment did not directly transform to tissue accumulation. This result showed that metal amounts in the tissues of the $P$. marmoratus did not reflect environmental contaminations and that sediment accumulated higher amounts of metals than seawater and tissues.
\end{abstract}

Key words: Correlation, metabolic pathways, transferrin, metallothionein.

Özet: Bu çalışma, bazı metallerin (Al, As, Cd, Cr, Cu, Fe, Mn, Ni, Pb ve Zn) Karadeniz (Ordu, Türkiye) kıyısı boyunca dere ve evsel atık bölgelerine yakın noktalardan örnekleme yapılmış mermer yengeci Pachygrapsus marmoratus (Fabricius)'un dış iskelet, solungaç, hepatopankreas ve kas dokularındaki birikim ilişkilerinini etkileşimlerini araştırmak amacıyla yapılmıştır. Karadeniz boyunca 28 km'lik bir kıyı şeridini kapsayan çalışma alanı 41 $03^{\prime} 46.42^{\prime \prime}-41^{\circ} 07^{\prime} 42.35$ "N enlemleri ve $37^{\circ} 28^{\prime} 45.63^{\prime \prime}-37^{\circ} 41^{\prime} 15.29^{\prime \prime} \mathrm{E}$ boylamları arasındadır. Numunelerin metal içerikleri indüktif eşleşmiş plazma - optik emisyon spektrometrisi (ICP-OES) tekniği ile analiz edilmiștir. Elde edilen sonuçlar birlikte değerlendirildiğinde, sedimentte $\mathrm{Fe}>\mathrm{Al}>\mathrm{Mn}>\mathrm{Zn}>\mathrm{Cr}>\mathrm{Pb}>\mathrm{Cu}>\mathrm{As}>\mathrm{Ni}>\mathrm{Cd}$, suda $\mathrm{Fe}>\mathrm{Mn}>\mathrm{Cr}>\mathrm{As}>\mathrm{Cd}$ ve yengeç dokularında $\mathrm{Al}>\mathrm{Fe}>\mathrm{Cu}>\mathrm{Mn}>\mathrm{Zn}$ şeklinde gözlenmiştir. Yengeç örneklerinde, tüm metallerin dokularda birikim miktarının sırası solungaç $>$ dış iskelet $>$ hepatopankreas $>$ kas şeklindedir. Al ve $\mathrm{Fe}$, sediment ve yengeç dokularında baskın metaller iken, deniz suyu örneklerinde Al tespit edilmemiştir. Sediment, su ve yengeç dokularında birikimin etkileşimini ortaya koymak için bir korelasyon testi yapılmıștır. Metal-metal etkileșimleri ve bunların birlikte birikimi korelasyon testi ile tespit edilmiștir. Yengeç dokularında gözlenen, ancak deniz suyu ve sedimentte bulunmayan bu etkileşimler çalışmanın temel noktasını oluşturmuştur. Metal-metal etkileşimleri arasında en fazla anlamlı korelasyon solungaç ve diş iskelette gözlenmiştir. Ayrıca, solungaçlarda ve dış iskeletlerde metal konsantrasyonları daha yüksek bulunmuştur. Dış iskelette $\mathrm{Mn}-\mathrm{Al}(\mathrm{r}=0,954$, korelasyon $\mathrm{p}<0,001)$, solungaçta $\mathrm{Al}-\mathrm{Fe}$ $(\mathrm{r}=0,849$, korelasyon $\mathrm{p}<0,001)$, Mn-Zn $(\mathrm{r}=0,854$, korelasyon $\mathrm{p}<0,001)$, hepatopankreasta Al-Zn $(\mathrm{r}=0,882$ korelasyon $\mathrm{p}<0,001)$ arasında kuvvetli korelasyonlar tespit edilmiștir. Hepatopankreasta $\mathrm{Zn}-\mathrm{Cu}$ arasında ise orta dereceli bir korelasyon bulunmuștur. Bu metal-metal etkileşimleri metallothionein aktivitesinin bir sonucu olabilir. Sediment örnekleri ve yengeç dokuları arasında anlamlı ilişki bulunamamıştır (korelasyon $\mathrm{p}>0,05$ ). Hatta sonuçlar göstermiştir ki deniz suyu ve sedimentindeki metaller, dokudaki birikime direkt dönüşmemiştir. $\mathrm{Bu}$ sonuç $P$. marmoratus'un dokularındaki metal miktarının çevresel kontaminasyonu yansıtmadığını göstermektedir ve aynı zamanda sediment sonuçlarının deniz suyu ve yengeç dokularından daha fazla metal birikimi miktarını gösterdiği tespit edilmiştir. 


\section{Introduction}

The coastal areas and estuaries which connect land and sea, provide spawning, nesting and feeding area, and transport nutrient and organic materials for crabs are critically important transition zones (CTZs) (Kasmin 2010). The CTZs fulfil fundamental ecological functions such as decomposition, nutrient cycle and nutrient production. Crabs living in such areas and the sediment present here are important components of these fundamental functions. The most critical function of crabs is achieved by enriching the sediment by processing organic material. Considering the fact that sea pollution is mostly caused by industrial, domestic and agricultural wastes, the major threats to biodiversity in the CTZs appear to be due to anthropogenic effects such as nontraditional pollutants (heavy metals, pesticides, new generation contaminants, drugs, nanoparticles, etc.), species invasions, overfishing, and climate change under the influence of industry, urbanisation and agricultural areas (Kasmin 2010).

CTZs and crabs in marine ecosystems can potentially be exposed to sub-lethal concentrations of a wide range of chemicals originating from anthropogenic sources. Considering the environmental conditions, the most dangerous environmental pollutants are heavy metals. It's a matter of vital importance to understand the existence, accumulation and distribution of heavy metals in marine ecosystems for which heavy metal pollution is a danger. Heavy metal accumulation in crab tissues can be higher than accumulation levels in seawater and sediment (Rainbow 2007), which may imply that there is an acceleration of environmental toxicity. This, in turn, raises the need of certain sensitive monitoring methods to be used to prevent, or least minimize, destructive effects of metal pollutions on marine species (Bresler et al. 2003).

There exist some monitoring systems which include chemical analysis of abiotic factors such as seawater and sediment. Although these monitoring systems produce accurate results, it is impossible to provide sufficient data on ecological situation when the number and range of contaminants exceed the ability of the chemical tests applied or when there are possible synergistic effects of contaminants on each other (Phillips \& Rainbow 1994).

Metals and metalloids are important environmental pollutants and may show severe acute or chronic effects on living organisms (Ullah et al. 2015). Species dispersed in various habitats can play an important role for ecosystems. For instance, any variable that affects crabs can have a major impact on the habitat and the ecosystem (Siddon \& Witman 2004, Pandya \& Vachharajani 2011, Trivedi et al. 2012, Arya et al. 2014). Crabs are a vital component of food chain in marine ecosystems, and control ecological function by feeding on both detritus and organic matter (Parsa et al. 2014). Pachygrapsus marmoratus (Fabricius) is the most common rocky shore inhabitant of the Mediterranean, Black Sea and East Atlantic coasts, and is active both under and above seawater for long periods of time (Cannicci et al. 1999).
Organisms need metals in varying quantities. A high concentration of any metal is toxic to organisms. Metal transporters, i.e. transferrin, natural resistance-associated macrophage protein (NRAMP) family, ZIP (ZRT and IRT-like protein) family, etc. are involved in the procurement of metals as in the case of transportation, storage and remobilization of metals to proteins that need metals in their structures (Kramer et al. 2007). Metals can accumulate in organisms through different metabolic pathways. These metabolic pathways are not selective about the metal since they can carry more than one metal (Menon et al. 2016). The lack of selectivity of the metabolic pathways leads to a competition between the metals and forms the basis of metal accumulation in organisms.

The studies performed with the aim of determination of metal levels in Black Sea region mostly used various fish species as an indication of accumulation of metal pollution in living organisms. In one of these study, Filazi et al. (2003) evaluated levels of $\mathrm{Cu} \mathrm{Pb}, \mathrm{Cd}, \mathrm{Cr}$ and $\mathrm{Ni}$ in liver and muscle tissues of Mugil auratus Risso (syn. Chelon auratus (Risso)) collected from Sinop-Icliman, Black Sea, Turkey and found that the highest level of accumulation was of $\mathrm{Pb}$. Tüzen (2003) determined concentrations of $\mathrm{Pb}, \mathrm{Cd}, \mathrm{Fe}, \mathrm{Cu}, \mathrm{Mn}$ and $\mathrm{Zn}$ in the fish species Alosa caspia (Eichwald), Engraulis encrasicholus (L.), Trachurus trachurus (L.), Sarda sarda (Bloch), and Clupea sprattus (L.) sampled from the middle Black Sea Region and found that levels of the essential metals in the samples were higher than those of the non-essential metals. Altas \& Büyükgüngör (2007) investigated the heavy metals levels in water samples of the Middle Black Sea region of Turkey from May 2000 to October 2001 and determined that $\mathrm{Cd}$ and $\mathrm{Cu}$ levels generally and $\mathrm{Pb}$ and $\mathrm{Zn}$ levels sometimes exceeded the levels reported in the Marine General Quality Criteria, while Ni concentrations were at desired levels. Makedonski et. al. (2017) were investigated $\mathrm{Cd}, \mathrm{As}, \mathrm{Hg}, \mathrm{Pb}, \mathrm{Zn}$ and $\mathrm{Cu}$ levels in edible parts and gills of seven Bulgarian fish species ((Sprattus sprattus (L.), Trachurus mediterraneus ponticus Aleev (syn. Trachurus mediterraneus (Steindachner)) Neogobius melanostomus (Pallas), Alosa pontica (Eichwald) (syn. Alosa immaculata (Bennett)), Sarda sarda, Pomatomus saltatrix (L.), Mugil cephalus L. collected from north-east coast of Black Sea and found that the metal concentrations were highest in the gills for all fish species, showing that metal accumulation varied between fish species, tissues and the metals analysed.

In the present study, the marbled crab Pachygrapsus marmoratus (Fabricius) sampled from different streams and domestic discharge points along the coastal region of Black Sea in Ordu, Turkey was investigated for accumulation levels of $\mathrm{Al}, \mathrm{As}, \mathrm{Cd}, \mathrm{Cr}, \mathrm{Cu}, \mathrm{Fe}, \mathrm{Mn}, \mathrm{Ni}, \mathrm{Pb}$ and $\mathrm{Zn}$ and in exoskeleton, gill, hepatopancreas and muscle tissues. The sediment and seawater samples from the crab sampling sites were also analysed for the same purpose. Pachygrapsus marmoratus was chosen as the 
study material because it has previously been reported as a bioindicator for metal accumulation (Álvaroa et al. 2016). The sampling localities were selected from the coastal region of Ordu where no former study has been performed addressing metal accumulation levels. The results were analysed based on metal-metal interactions and co-accumulations and the obtained data was discussed with regard to the effects of metabolic pathways in co-accumulation.

\section{Materials and Methods}

\section{Sample collection}

The samples included in the study were obtained in February 2015 from 8 different stations along the coastal region of Black Sea in Ordu in Black Sea Region of Turkey. Stations were selected near from streams (Bolaman, Elekçi, Ilıca and Çalış) and domestic discharge points near human settlements (Fig. 1).

Table 1. Latitude and longitude of the sampling stations.

\begin{tabular}{ccc}
\hline Station & Latitude & Longitude \\
\hline \hline S1 & $41^{\circ} 03^{\prime} 46.42^{\prime \prime} \mathrm{N}$ & $37^{\circ} 28^{\prime} 45.63^{\prime \prime} \mathrm{E}$ \\
S2 & $41^{\circ} 02^{\prime} 18.59^{\prime \prime} \mathrm{N}$ & $37^{\circ} 29^{\prime} 33.06^{\prime \prime} \mathrm{E}$ \\
S3 & $41^{\circ} 01^{\prime} 17.57^{\prime \prime} \mathrm{N}$ & $37^{\circ} 32^{\prime} 13.97^{\prime \prime} \mathrm{E}$ \\
S4 & $41^{\circ} 02^{\prime} 01.92^{\prime \prime} \mathrm{N}$ & $37^{\circ} 35^{\prime} 02.09^{\prime \prime} \mathrm{E}$ \\
S5 & $41^{\circ} 02^{\prime} 57.34^{\prime \prime} \mathrm{N}$ & $37^{\circ} 36^{\prime} 35.45^{\prime \prime} \mathrm{E}$ \\
S6 & $41^{\circ} 04^{\prime} 51.87^{\prime \prime} \mathrm{N}$ & $37^{\circ} 37^{\prime} 44.11^{\prime \prime} \mathrm{E}$ \\
S7 & $41^{\circ} 066^{\prime} 30.37^{\prime \prime} \mathrm{N}$ & $37^{\circ} 39^{\prime} 06.73 " \mathrm{E}$ \\
S8 & $41^{\circ} 07^{\prime} 42.35^{\prime \prime} \mathrm{N}$ & $37^{\circ} 41^{\prime} 15.29^{\prime \prime} \mathrm{E}$ \\
\hline \hline
\end{tabular}

The study area covered a coastal stretch of $28 \mathrm{~km}$ along Black Sea (Figure 1, Table 1). The 10 male crab samples from each location $(\mathrm{N}=80)$ were randomly collected directly by hand picking. Only male individuals were studied to prevent the results will not affect from gender. 2 surface seawater and 2 surface sediment samples from each station $(\mathrm{N}=16)$ were also sampled from the crab sampling sites.

\section{Metal Analysis}

Male crabs were immediately transported live to Toxicology Laboratory of Ankara University in frosted plastic storage boxes and stored at $-20^{\circ} \mathrm{C}$ until the analyses performed. All samples were dissected immediately to obtain the tissues for metal analysis. Approximately $2 \mathrm{~g}$ of tissue samples were taken from hepatopancreas, muscles, exoskeleton and gills through dissection and all were digested for the inductively coupled plasma/optical emission spectroscopy (ICPOES) (Agilent, 5110) analysis. Tissue samples were placed in porcelain crucibles, dried at $50-60^{\circ} \mathrm{C}$ for $24 \mathrm{~h}$ and then weighed to determine their net dry weights. Approximately $1 \mathrm{~g}$ of each tissue sample was used for the measurements. $3 \mathrm{~mL}$ of nitric acid $\left(\mathrm{HNO}_{3}\right)$ (Merck) were added to the dried tissue samples. The tissues were kept at $100^{\circ} \mathrm{C}$ temperature for $20 \mathrm{~min}$ on a heating table to achieve a thorough digestion (Núñez-Nogueira et al. 2013). After the samples were cooled, $5 \mathrm{~mL}$ of distilled water (pure water) was added on each. The samples were then filtered with a $0.45 \mu \mathrm{m}$ pore size glass microfiber Whatman filter paper with the help of a syringe.

Sediment samples were taken superficially from the same coordinates with a Bridge-Ekman grab sampler from sampling stations and samples were put in plastic containers. Both seawater and sediment samples were kept at $4{ }^{\circ} \mathrm{C}$ prior to analysis. The water samples were acidified with $\mathrm{HNO}_{3}$ at $\mathrm{pH} 2$ and filtered before analysis. The samples were read in triplicate. Prior to analysis, the sediment samples were combined in a FRITSCH tungsten carbide mortar, mixed with the binder material (Wachs) at ICP-OES measurements. The sediment and seawater samples were analyzed by ICP-OES. It was service procurement from Cinar Engineering Consulting Co. for the reading of the samples. Reference materials (CRMMess 4 for sediment and LUTS- 1 for tissues) were also analysed to avoid any error with samples. The reference material values and control samples results displayed good harmony between each other.

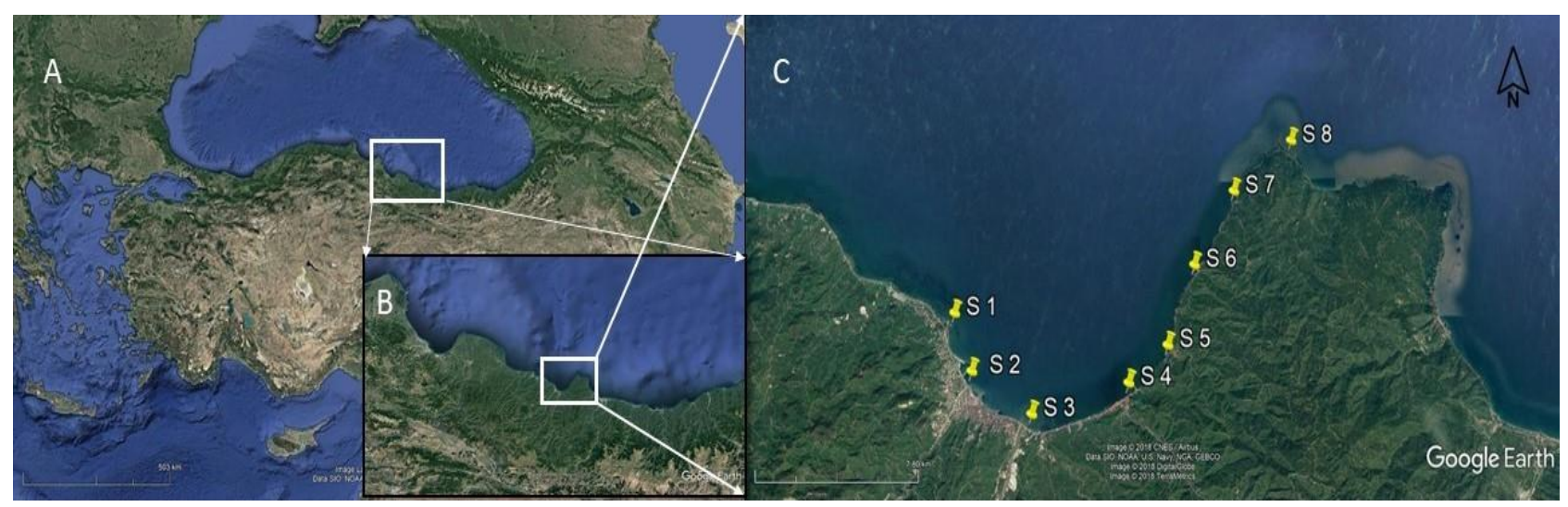

Fig. 1. The map showing the sampling locations. (A) Turkey, (B) Ordu province (C) Sampling Stations 


\section{$\underline{\text { Statistical Analyses }}$}

All statistical analyses were performed by the SPSS 21.0v. software. Prior to analysis, all results were subjected to the Kolmogorov-Smirnov test to observe the normality of data distribution. Data sets that fit a parametric distribution were analysed by the Pearson's correlation test, whereas those which did not fit a parametric distribution were analysed by the Spearman's correlation rank test. Mann-Whitney U-test test was used to investigate the accumulation differences in nonparametric data.

\section{Results}

The results showed that among the tested metals, only $\mathrm{Al}, \mathrm{Cu}, \mathrm{Fe}, \mathrm{Mn}$ and $\mathrm{Zn}$ were detected in the crab tissues. When the accumulation levels of these metals were evaluated in all the tissues as a whole, the highest accumulation value was determined for $\mathrm{Al}$ followed by
$\mathrm{Fe}, \mathrm{Cu}, \mathrm{Mn}$ and $\mathrm{Zn}$ (Table 2). The correlation analysis results revealed different correlation values for metal pairs for each tissue (Table 3). The correlations were strong and very strong for most of the pairs. The tissues were examined to investigate the metal co-accumulation tendency (Table 3). Gills and exoskeleton were found to show the greatest number of significant correlations of metal-metal interactions (Table 3). Strong correlations between $\mathrm{Mn}-\mathrm{Al}(\mathrm{r}=0.954, \mathrm{p}<0.001)$, in the exoskeleton, $\mathrm{Al}-\mathrm{Fe}(\mathrm{r}=0.849, \mathrm{p}<0.001)$ and $\mathrm{Mn}-\mathrm{Zn}(\mathrm{r}=0.854, \mathrm{p}<0.001)$ in the gills and Al-Zn $(r=0.882, p<0.001)$ in the hepatopancreas were noted.

The results showed that metal concentrations were found to be very lower in seawater samples than sediment samples (Table 4). The predominant metals in the sediment were $\mathrm{Al}$ and $\mathrm{Fe}$.

Table 2. Mean values of metal concentrations in crab tissues ( $\mu \mathrm{g} / \mathrm{g}$ dry weight).

\begin{tabular}{lccccc}
\hline \hline \multicolumn{1}{c}{ Tissues } & $\mathbf{A l}$ & $\mathbf{C u}$ & $\mathbf{F e}$ & $\mathbf{M n}$ & $\mathbf{Z n}$ \\
\hline \hline \multirow{2}{*}{ Hepatopancreas } & $123.4 \pm 12.9$ & $12.1 \pm 3.2$ & $9.1 \pm 1.4$ & $2.2 \pm 1.3$ & $4.2 \pm 2.1$ \\
& $(25.5-325.9)$ & $(1.7-35.6)$ & $(1.3-13.8)$ & $(1.1-4.1)$ & $(1.4-7.9)$ \\
Exoskeleton & $711.6 \pm 28.4$ & $14.3 \pm 5.2$ & $79.2 \pm 11.7$ & $6.4 \pm 2.3$ & $6.5 \pm 2.3$ \\
& $(74.3-1658)$ & $(4.7-42.2)$ & $(10.2-161.8)$ & $(1.8-10.7)$ & $(4.2-8.8)$ \\
Muscle & $20.9 \pm 12.7$ & $7.4 \pm 1.7$ & $4.0 \pm 1.1$ & $1.7 \pm 0.5$ & $2.0 \pm 0.7$ \\
& $(6.0-35.7)$ & $(1.04-26.02)$ & $(0.6-8.2)$ & $(0.5-, 3.6)$ & $(0.6-3.04)$ \\
Gills & $806.0 \pm 100.6$ & $17.8 \pm 8.6$ & $120.0 \pm 12.5$ & $11.5 \pm 3.1$ & $10.9 \pm 4.9$ \\
& $(97.4-1674.8)$ & $(10.8-23.6)$ & $(9.8-241.7)$ & $(3.9-20.9)$ & $(8.4-15.3)$ \\
\hline \hline
\end{tabular}

Table 3. Correlations of accumulation levels of metal pairs in crab tissues.

\begin{tabular}{|c|c|c|c|c|c|c|c|c|c|c|}
\hline & & All tissues & $\mathrm{Fe}$ & $\mathrm{Cu}$ & Zn & Al & & & \\
\hline & & $\begin{array}{l}\mathrm{Cu} \\
p \\
\mathrm{Zn} \\
p \\
\mathrm{Al} \\
p \\
\mathrm{Mn} \\
\underline{\mathbf{p}} \\
\end{array}$ & & $\begin{array}{l}.604^{* *} \\
.000 \\
.576^{* *} \\
.000 \\
.840^{* *} \\
.000 \\
.431^{* *} \\
.001 \\
\end{array}$ & $\begin{array}{l}.760^{* *} \\
.000 \\
.560^{* *} \\
.000 \\
.483^{* *} \\
.000 \\
\end{array}$ & $\begin{array}{l}.582^{* *} \\
.000 \\
.435^{* *} \\
.001 \\
\end{array}$ & $\begin{array}{l}.487^{* *} \\
.000 \\
\end{array}$ & & & \\
\hline Exoskeleton & $\mathbf{F e}$ & $\mathbf{C u}$ & Zn & Al & Hepat & pancreas & $\mathrm{Fe}$ & $\mathrm{Cu}$ & $\mathbf{Z n}$ & Al \\
\hline $\begin{array}{l}\mathrm{Cu} \\
p\end{array}$ & $\begin{array}{l}.628^{*} \\
0.007\end{array}$ & & & & & & $\begin{array}{l}.782^{* * *} \\
.001\end{array}$ & & & \\
\hline Zn & $.654^{* *}$ & $.700^{* * *}$ & & & $\mathrm{Zn}$ & & $.618^{*}$ & $.782^{* *}$ & & \\
\hline$p$ & .008 & .004 & & & $p$ & & .014 & .001 & & \\
\hline Al & $.664^{* *}$ & 0.496 & $.714^{* *}$ & & Al & & $.632^{*}$ & $.679^{* *}$ & $.882^{* *}$ & \\
\hline$p$ & .007 & .060 & .003 & & $p$ & & .011 & .005 & .000 & \\
\hline Mn & $.752^{* *}$ & $.588^{*}$ & $.758^{* *}$ & $.954^{* *}$ & Mn & & -0.504 & -0.175 & -0.375 & -0.439 \\
\hline$p$ & .001 & .021 & .001 & .000 & $\underline{p}$ & & .056 & .533 & .168 & .101 \\
\hline Gills & $\mathrm{Fe}$ & $\mathrm{Cu}$ & $\mathbf{Z n}$ & Al & & iscle & $\mathrm{Fe}$ & $\mathrm{Cu}$ & $\mathbf{Z n}$ & Al \\
\hline$\overline{\mathrm{Cu}}$ & $.571^{*}$ & & & & $\overline{\mathrm{Cu}}$ & & -.150 & & & \\
\hline$p$ & .026 & & & & $p$ & & .593 & & & \\
\hline $\mathbf{Z n}$ & $.618^{*}$ & $.764^{* *}$ & & & Zn & & -0.271 & $.729^{* *}$ & & \\
\hline$p$ & .014 & .001 & & & $p$ & & .328 & .002 & & \\
\hline Al & $.849^{* *}$ & 0.481 & $.549^{*}$ & & Al & & $.575^{*}$ & .048 & -.100 & \\
\hline$p$ & .000 & .070 & .034 & & $p$ & & .025 & .864 & .723 & \\
\hline Mn & $.679^{* * *}$ & $.725^{* *}$ & $.854^{* *}$ & $.690^{* *}$ & Mn & & -.150 & .445 & .421 & .343 \\
\hline$p$ & .005 & .002 & .000 & .004 & $p$ & & .594 & .096 & .118 & .211 \\
\hline
\end{tabular}

*The mean difference is significant at the 0.05 level $(p<0.05)$.

$* *$ The mean difference is significant at the 0.01 level $(p<0.01)$. 
Table 4. Metal concentrations in sediment $(\mu \mathrm{g} / \mathrm{g})$ and seawater $(\mu \mathrm{g} / \mathrm{L})$ samples.

\begin{tabular}{|c|c|c|c|c|c|c|c|c|c|c|}
\hline Sediment & Al & As & Cd & $\mathrm{Cr}$ & $\mathrm{Cu}$ & $\mathbf{F e}$ & Mn & $\mathbf{N i}$ & $\mathbf{P b}$ & $\mathbf{Z n}$ \\
\hline \multirow[b]{2}{*}{ S1 } & 12560.2 & 12 & 0.08 & 18.9 & 25.8 & 15432 & 316.2 & 12.8 & 20.8 & 30.9 \\
\hline & 14499.4 & 8 & 0.12 & 19.1 & 20 & 12774.2 & 400.6 & 14 & 17.6 & 81.3 \\
\hline \multirow[b]{2}{*}{$\mathbf{S 2}$} & 13002.2 & 23.7 & 0.09 & 38.9 & 28.3 & 10937.8 & 432.2 & 17.3 & 24.7 & 79.8 \\
\hline & 9050.4 & 12.3 & 0.11 & 41.1 & 10.1 & 31156.8 & 554 & 12.1 & 20.9 & 59.6 \\
\hline \multirow{2}{*}{ S3 } & 8931.3 & 22.8 & 0.18 & 33 & 16.1 & 21537.6 & 602.3 & 16.1 & 27.3 & 81.2 \\
\hline & 7415.9 & 14.8 & 0.22 & 22.8 & 15.1 & 12830.8 & 552.1 & 14.1 & 23.5 & 57.8 \\
\hline \multirow{2}{*}{ S4 } & 14992.9 & 14 & 0.05 & 17.5 & 10.7 & 21823.9 & 389 & 14.7 & 26.3 & 76.5 \\
\hline & 12767.9 & 7 & 0.15 & 7.5 & 14.3 & 10190.7 & 507.2 & 16.1 & 12.1 & 106.5 \\
\hline \multirow[b]{2}{*}{ S5 } & 14322.8 & 12.8 & 0.1 & 14.2 & 12.3 & 18348 & 332.5 & 20 & 20.6 & 27.4 \\
\hline & 14295.6 & 6 & 0.1 & 12.2 & 15.1 & 10456 & 381.9 & 15.2 & 17.6 & 77 \\
\hline \multirow{2}{*}{ S6 } & 11657.8 & 21.3 & 0.19 & 21.3 & 18.9 & 20962.6 & 496.9 & 14 & 25.2 & 37.9 \\
\hline & 12268 & 14.7 & 0.21 & 30.1 & 12.1 & 20136.2 & 476.5 & 12 & 14.4 & 67.3 \\
\hline \multirow{2}{*}{ S7 } & 17891.7 & 12.1 & 0.08 & 32.4 & 22.1 & 23656.9 & 666.8 & 13.3 & 27.3 & 101.7 \\
\hline & 6850.7 & 26.3 & 0.12 & 34 & 16.3 & 22247.7 & 484.4 & 13.1 & 18.5 & 89.7 \\
\hline \multirow{2}{*}{ S8 } & 8449.5 & 17.2 & 0.31 & 17.1 & 25.5 & 18932.8 & 382.3 & 17.2 & 18.4 & 62.3 \\
\hline & 14578.5 & 22 & 0.09 & 13.1 & 22.9 & 22766.2 & 498.7 & 18 & 31 & 57.3 \\
\hline Mean \pm SD & $\begin{array}{r}12095.9 \pm \\
3035.5\end{array}$ & $15.4 \pm 6.01$ & $0.14 \pm 0.07$ & $23.33 \pm 9.9$ & \pm 5.5 & $\begin{array}{r}18386.9 \pm \\
5664.2\end{array}$ & $\begin{array}{r}467.1 \pm \\
94.8 \\
\end{array}$ & $15 \pm 2.2$ & $21.6 \pm 4.99$ & $68.4 \pm 22.3$ \\
\hline Seawater & Al & As & Cd & $\mathrm{Cr}$ & $\mathbf{C u}$ & $\mathrm{Fe}$ & Mn & $\mathbf{N i}$ & $\mathbf{P b}$ & $\mathbf{Z n}$ \\
\hline \multirow{2}{*}{ S1 } & N.D. & $\overline{1.2}$ & $\overline{1.3}$ & 0.7 & N.D. & 658.7 & 145.8 & N.D. & N.D. & $\overline{\text { N.D. }}$ \\
\hline & N.D. & 0.6 & 1.1 & 0.5 & N.D. & 564.9 & 211.8 & N.D. & N.D. & N.D. \\
\hline \multirow{2}{*}{ S2 } & N.D. & 1.3 & 0.3 & 1.7 & N.D. & 892.6 & 159.3 & N.D. & N.D. & N.D. \\
\hline & N.D. & 0.5 & 0.7 & 1.1 & N.D. & 816.8 & 91.7 & N.D. & N.D. & N.D. \\
\hline \multirow{2}{*}{$\mathbf{S 3}$} & N.D. & 0.8 & 1.1 & 0.8 & N.D. & 554.2 & 102.9 & N.D. & N.D. & N.D. \\
\hline & N.D. & 0.6 & 0.7 & 1 & N.D. & 359.3 & 90.9 & N.D. & N.D. & N.D. \\
\hline \multirow{2}{*}{ S4 } & N.D. & 0.9 & 0.3 & 0.3 & N.D. & 743.6 & 103 & N.D. & N.D. & N.D. \\
\hline & N.D. & 1.7 & 0.7 & 0.5 & N.D. & 721.4 & 117.6 & N.D. & N.D. & N.D. \\
\hline \multirow{2}{*}{ S5 } & N.D. & 0.8 & 0.9 & 0.9 & N.D. & 1021.6 & 129.5 & N.D. & N.D. & N.D. \\
\hline & N.D. & 0.6 & 0.7 & 0.7 & N.D. & 518.2 & 108.7 & N.D. & N.D. & N.D. \\
\hline \multirow{2}{*}{ S6 } & N.D. & 1.1 & 0.3 & 0.2 & N.D. & 903.2 & 192.3 & N.D. & N.D. & N.D. \\
\hline & N.D. & 0.5 & 0.5 & 0.6 & N.D. & 579.8 & 78.7 & N.D. & N.D. & N.D. \\
\hline \multirow[b]{2}{*}{ S7 } & N.D. & 0.8 & 0.6 & 0.8 & N.D. & 432.2 & 129 & N.D. & N.D. & N.D. \\
\hline & N.D. & 0.8 & 0.6 & 0.4 & N.D. & 442 & 126 & N.D. & N.D. & N.D. \\
\hline \multirow[b]{2}{*}{ S8 } & N.D. & 0.9 & 0.3 & 0.3 & N.D. & 506.3 & 120.2 & N.D. & N.D. & N.D. \\
\hline & N.D. & 1.1 & 0.5 & 0.5 & N.D. & 602.1 & 100 & N.D. & N.D. & N.D. \\
\hline Mean \pm SD & N.D. & $0.9 \pm 0.3$ & $0.7 \pm 0.3$ & $0.7 \pm 0.4$ & N.D. & $\begin{array}{r}644.8 \pm \\
183.6\end{array}$ & $\begin{array}{r}125.5 \pm \\
35.4\end{array}$ & N.D. & N.D. & N.D. \\
\hline
\end{tabular}

N.D.: Not Detected.

Correlation analyses were also performed to reveal metal-metal accumulation interactions, if any, in seawater and sediment samples (Table 5). Some correlations determined in the crab tissues but not in seawater and sediment samples were considered as indicators of metal-metal interactions and coaccumulation. Significant correlations in the sediment samples were among $\mathrm{Mn}-\mathrm{Pb}(\mathrm{r}=0.743, \mathrm{p}=0.035), \mathrm{As}-\mathrm{Pb}$ $(\mathrm{r}=0.916, \mathrm{p}=0.01), \mathrm{As}-\mathrm{Fe}(\mathrm{r}=0.790, \mathrm{p}=0.02), \mathrm{Cr}-\mathrm{Mn}$ $(\mathrm{r}=0.738, \mathrm{p}=0.37), \mathrm{Al}-\mathrm{Pb}(\mathrm{r}=-0.874, \mathrm{p}=0.005)$ and $\mathrm{Al}-$ $\mathrm{Mn}(\mathrm{r}=-0.714, \mathrm{p}=0.047)$. The level of correlation between metal concentrations in crab tissues and the sediment samples were also tested but no significant correlation was determined whereas significant correlations were observed between concentration values in crab tissues (Table 6). The results showed that metals present in the seawater and sediment did not directly transformed to accumulations in crab tissues.

\section{Discussion}

The accumulation orders of metals were determined as $\mathrm{Al}>\mathrm{Fe}>\mathrm{Cu}>\mathrm{Mn}>\mathrm{Zn}$ in crab tissues, $\mathrm{Fe}>\mathrm{Mn}>\mathrm{Cr}>\mathrm{As}>\mathrm{Cd}$ in the seawater and $\mathrm{Fe}>\mathrm{Al}>\mathrm{Mn}>\mathrm{Zn}>\mathrm{Cr}>\mathrm{Pb}>\mathrm{Cu}>\mathrm{As}>\mathrm{Ni}>\mathrm{Cd}$ in the sediment. $\mathrm{Al}$ and $\mathrm{Fe}$ were found to be predominant metals in the sediment but $\mathrm{Al}$ was not detected in the water samples. This may be related to the fact that sediment particles tend to absorb metals in the water, and this metal with high molecular weight tend to precipitate at the bottom (Table 2, 4).

Metal concentrations in the sediment and seawater samples were measured to determine whether accumulation levels in crab tissues signify environmental contamination. Compared to the crab tissues and 
seawater, there were higher levels of metal concentrations in the sediment. This can be attributed to the fact that the sediment in wetlands assumes a storage role in terms of heavy metal accumulation. It has been reported that sediment accumulates metals at higher amounts compared to water and tissues (Mendil \& Uluözlü 2007, Yildiz \& Yener 2010, Oner \& Celik 2011, Kir \& Tumantozlu 2012, Fikirdeşici Ergen et al. 2015).

Although a positive strong correlation between $\mathrm{As}-\mathrm{Pb}$ $(\mathrm{r}=0.916, \mathrm{p}=0.001)$ and a negative strong correlation between $\mathrm{Al}-\mathrm{Pb}(\mathrm{r}=0.874, \mathrm{p}=0.005)$ were determined in sediment samples, there was no correlation among the metals in seawater samples. This means that the metal concentrations in the sediment were not affected by the changes in the seawater samples. This can also be explained by the fact that metals are under the influence of processes such as absorption and desorption (Hung et al. 2001).

Among the investigated metals, only $\mathrm{Fe}, \mathrm{Cu}, \mathrm{Zn}, \mathrm{Al}$ and $\mathrm{Mn}$ were detected in crab tissues. The amount of accumulation of these metals in crab tissues revealed an order as gills>exoskeleton>hepatopancreas>muscle (Table 2) most probably because gills and exoskeleton tissues are in contact with the external environment (Tunca et al. 2013a). The accumulation level of metals in the muscle tissue is less than the other tissues. This can be explained by the limited occurrence of metal binding proteins in muscle tissue (Guner 2007). Al was determined at high levels in all tissues. Gills in particular accumulated A1 at higher levels compared to other tissues. The levels of $\mathrm{Al}$ accumulation in hepatopancreas and muscle were lower than in the gills and exoskeleton as reported in previous studies (Alexopoulos et al. 2003, Kurun et al.2010, Tunca et al. 2013b). The gills are the primary sites for the uptake of soluble metals from the aquatic environment (Walton et al. 2010). Gills were found to be the prime site of $\mathrm{Al}$ accumulation in this work. There was higher accumulation level of $\mathrm{Al}$ in the tissues $(\mathrm{p}<0.05)$ since it is as an essential element (Woodburn et al. 2011) and also essential metals were reported to be transported to other organs by the gills (Nott 1991, Guner 2007). The results of these studies also showed that gills play an important role in $\mathrm{Al}$ intake and this intake cause excessive mucus secretion.

Metal uptake and accumulation can be facilitated by respiration and digestion in aquatic animals. Metals have a point of entry from the environment to the animal's body. Gills and exoskeleton are the primary point of entry and they revealed the greatest number of significant correlations of metal-metal interactions in the present study (Table 3 ).

Table 5. Correlations between metal pairs in seawater and sediment samples.

\begin{tabular}{lllllllllll}
\hline \hline Sediment & $\mathrm{Cu}$ & $\mathrm{Pb}$ & $\mathrm{Zn}$ & $\mathrm{Ni}$ & $\mathrm{Mn}$ & $\mathrm{Fe}$ & As & $\mathrm{Cd}$ & $\mathrm{Cr}$ \\
\hline \hline
\end{tabular}

\begin{tabular}{|c|c|c|c|c|c|c|c|c|c|}
\hline $\begin{array}{l}\mathrm{Pb} \\
p\end{array}$ & $\begin{array}{l}0.494 \\
.213\end{array}$ & & & & & & & & \\
\hline Zn & 0.072 & 0.431 & & & & & & & \\
\hline$p$ & .866 & .286 & & & & & & & \\
\hline $\mathrm{Ni}$ & -0.096 & -0.084 & -0.156 & & & & & & \\
\hline$p$ & .820 & .843 & .713 & & & & & & \\
\hline Mn & 0.012 & $.743^{*}$ & 0.643 & -0.455 & & & & & \\
\hline$p$ & .978 & .035 & .086 & .257 & & & & & \\
\hline $\mathrm{Fe}$ & 0.323 & 0.647 & 0.571 & -0.287 & 0.643 & & & & \\
\hline$p$ & .435 & .083 & .139 & .490 & .086 & & & & \\
\hline As & 0.524 & $.916^{* *}$ & 0.479 & -0.096 & 0.611 & $.790^{*}$ & & & \\
\hline$p$ & .182 & .001 & .230 & .820 & .108 & .020 & & & \\
\hline Cd & 0.17 & 0.624 & -0.282 & 0 & 0.282 & 0.169 & 0.567 & & \\
\hline$p$ & .687 & .099 & .499 & 1.000 & .499 & .689 & .143 & & \\
\hline $\mathrm{Cr}$ & 0.395 & 0.563 & 0.357 & -0.611 & $.738^{*}$ & 0.667 & 0.443 & 0.056 & \\
\hline$p$ & .333 & .146 & .385 & .108 & .037 & .071 & .272 & .895 & \\
\hline Al & -0.443 & $-.874^{* * *}$ & -0.238 & 0.18 & $-.714^{*}$ & -0.548 & -0.695 & -0.62 & -0.69 \\
\hline$p$ & .272 & .005 & .570 & .670 & .047 & .160 & .056 & .101 & .058 \\
\hline Seawater & Mn & $\mathbf{F e}$ & As & Cd & & & & & \\
\hline $\mathbf{F e}$ & 0.214 & & & & & & & & \\
\hline$p$ & .610 & & & & & & & & \\
\hline As & 0.012 & 0.073 & & & & & & & \\
\hline$p$ & .977 & .864 & & & & & & & \\
\hline Cd & 0.108 & -0.241 & -0.442 & & & & & & \\
\hline$p$ & .798 & .565 & .273 & & & & & & \\
\hline $\mathrm{Cr}$ & 0.22 & 0.39 & -0.522 & -0.173 & & & & & \\
\hline$p$ & .601 & .339 & .185 & .682 & & & & & \\
\hline
\end{tabular}

*The mean difference is significant at the 0.05 level $(p<0.05)$.

$* *$ The mean difference is significant at the 0.01 level $(p<0.01)$. 
Table 6. Correlations between metal levels in crab tissues and the sediment samples.

\begin{tabular}{lllll}
\hline \hline & Hepatopancreas & Exosceleton & Muscle & Gills \\
\hline \hline Exosceleton $.818^{* *}$ & .004 & & & \\
$\boldsymbol{p}$ & $.842^{* *}$ & $.927^{* *}$ & & \\
Muscle & .002 & .000 & & \\
$\boldsymbol{p}$ & $.903^{* *}$ & $.794^{* *}$ & $.782^{* *}$ & \\
Gills & .000 & .006 & .008 & \\
$\boldsymbol{p}$ & .073 & -.220 & -.134 & .152 \\
Sediment & .073 & .542 & .712 & .674 \\
$\underline{p}$ & .841 & &
\end{tabular}

Exposure time and metal concentrations are some of the important reasons for bioaccumulation (Anderson $e t$ al. 1997). Therefore, different tissues in an organism or the same tissues in different individuals of the same organism can accumulate high concentrations of the same metal. So, it is possible to find examples for that different tissues accumulate same metals. For instance, Chagas et al. (2009) found that hepatopancreas was the main tissue to accumulate $\mathrm{Mn}$, whereas in the present study, the results indicated gills as the principal site of accumulation for $\mathrm{Mn}$. The strongest correlation was found between Mn$\mathrm{Al}(\mathrm{r}=0.954, \mathrm{p}<0.001)$ in the exoskeleton. Moderate correlation was determined between $\mathrm{Mn}-\mathrm{Al}(\mathrm{r}=0.690$, $\mathrm{p}=0.004$ ) in the gills but not in hepatopancreas and muscle (Table 3). This suggests that $\mathrm{Mn}$ and $\mathrm{Al}$ can have the same natural origin and there are similarities between the adsorption chemistries of these metals. In addition, the correlation between $\mathrm{Mn}-\mathrm{Al}$ might be due to the transportation of these metals by transferrin protein because common use of metabolic pathways can lead to strong correlations in tissues (Cohen et al. 1998). However, negative moderate correlation between $\mathrm{Mn}-\mathrm{Al}$ $(\mathrm{r}=-0.714, \mathrm{p}=0.047)$ was determined in sediment samples which points out that the sighted effect is not a reflection of metal background in the environment (Table 5). This might be related with the fact that there is an antagonism between these metals during absorption and it may be related with the competitive effects over transferrin binding. Transferrin has an important role especially in the transport of Fe (Chua et al. 2007) but it also plays a role in transports of $\mathrm{Al}^{3+}, \mathrm{Cr}^{3+}, \mathrm{Cu}^{2+}, \mathrm{Ga}^{3+}, \mathrm{Ni}^{2+}, \mathrm{Ti}^{4+}$ and $\mathrm{Zn}^{2+}$ (Quarles et al. 2011). A positive strong correlation between $\mathrm{Mn}-\mathrm{Zn}(\mathrm{r}=0.854, \mathrm{p}<0.001)$ in the gills and a moderate correlation $(\mathrm{r}=0.758, \mathrm{p}=0.001)$ in the exoskeleton were found while there were no correlations between these metals in the hepatopancreas and muscle. Bervoets et al. (2001) found the same strong correlation between $\mathrm{Mn}-\mathrm{Zn}$ in the gills of the Gastrosteus aculeatus L.

A strong correlation was determined between $\mathrm{Al}-\mathrm{Fe}$ in the gills $(\mathrm{r}=0.849, \mathrm{p}<0.001)$ whereas a moderate correlation was determined between $\mathrm{Al}-\mathrm{Fe}$ in other tissues. All correlations between $\mathrm{Al}$ and $\mathrm{Fe}$ were found to be positive. Kurun et al. (2010) reported similar correlations between $\mathrm{Al}$ and $\mathrm{Fe}$ accumulations in the crayfish Astacus leptodactylus (Eschscholtz). This result may be due to one or more of the following items: (1) similarities of $\mathrm{Fe}$ and $\mathrm{Al}$ in metal adsorption kinetics, (2) similar chemical properties of $\mathrm{Fe}$ and $\mathrm{Al}$, (3) the major protein, transferrin which plays a major role in the $\mathrm{Fe}$ transport and Al absorption (Moshtaghie \& Taher 1993). The correlation results of $\mathrm{Al}$ accumulation with $\mathrm{Cu}$ and $\mathrm{Zn}$ are remarkable in hepatopancreas since hepatopancreas is the central place for accumulation of various metals and detoxification in decapod crustaceans (Tunca et al. 2013a).

Moderate correlation between $\mathrm{Zn}$ and $\mathrm{Fe}$ accumulations in hepatopancreas $(\mathrm{r}=0.618, \mathrm{p}=0.014)$, exoskeleton $(\mathrm{r}=0.654, \mathrm{p}=0.008)$, and gills $(\mathrm{r}=0.618$, $\mathrm{p}=0.014$ ) were determined whereas there was no correlation between $\mathrm{Zn}$ and $\mathrm{Fe}$ accumulations in muscle. $\mathrm{Zn}$ is an important essential metal for decapods and serves as a cofactor for the enzymatic systems. Additionally, metalloenzymes use $\mathrm{Zn}$ as the active core (Alcorlo et al. 2006). A moderate correlation was determined between $\mathrm{Cu}$ and $\mathrm{Fe}$ accumulations in hepatopancreas ( $\mathrm{r}=0.782$, $\mathrm{p}=0.001)$, exoskeleton $(\mathrm{r}=0.628, \mathrm{p}=0.007)$ and gills $(\mathrm{r}=0.571, \mathrm{p}=0.026)$ whereas there was no correlation present between $\mathrm{Cu}$ and $\mathrm{Fe}$ accumulations in muscle. The exoskeleton serves as a structural support and has biomineral composite, so it tends to accumulate copper from the water environment (Soedarini et al. 2012). Gills, the respiratory organs of crabs, were indicated to be sensitive to changes in copper concentrations in seawater. Copper in the water binds to hemocyanin by respiration and then circulated to all organs of the crustacean.

Some of the metal-metal correlations found in gills, exoskeleton and hepatopancreas were not present in the muscle tissues. A metal should gain an entry point from the gills and the exoskeleton to be transported to another tissue. For this reason, high correlations in these tissues are expected. Furthermore, especially gills are primary site of metal entry because they are rich in blood vessels. Gills are under effects of a blood-borne transfer protein such as transferrin so they may be related to metal-metal interactions more than other tissues. Another reason may be that the binding proteins are more prominent in the gills (Guner 2007). The lack of correlations in the muscle tissue can be explained by the lack of these proteins in the muscle tissue.

A moderate correlation between $\mathrm{Zn}-\mathrm{Cu}$ was found in all tissues but the correlation in hepatopancreas was slightly higher $(\mathrm{r}=0.782, \mathrm{p}=0.001)$. Metallothioneins are one of the most important metal sequestrating protein families and hepatopancreas is a main site of metal sequestration in crustaceans. Metallothioneins plays an important role in preventing undesirable reactions in the transfer of IB and IIB metals such as $\mathrm{Zn}, \mathrm{Cu}$ and $\mathrm{Hg}$ (Naji et al. 2014). For this reason, they are important proteins in preventing metal toxicity. If they are found in hepatopancreas at high concentrations, they help detoxify dangerous metals (Pourang et al. 2005). The production of the metallothionein in hepatopancreas is correlated with $\mathrm{Zn}$ and $\mathrm{Cu}$ accumulation in this tissue. Bochenek et al. (2008) found relationships between tissues (kidney, liver, gill and muscle) concentrations of $\mathrm{Zn}$ and $\mathrm{Cu}$ of the 
Rutilus rutilus (L.) and the sediment. In the present study, no correlation between $\mathrm{Zn}-\mathrm{Cu}$ was determined in sediment samples.

When the correlations among tissues were examined, it was determined that the highest correlation was between muscle-exoskeleton $(\mathrm{r}=0.927, \quad \mathrm{p}<0.001)$ and gillshepatopancreas $(r=0.903, p<0.001)$. These results were similar to study of the Fikirdesici Ergen et al. (2015). There was also a high correlation between hepatopancreas-muscle and gills, and moderate correlations between gills-muscle and hepatopancreas (Table 6).

\section{Conclusion}

In conclusion, as a result of examining the metal accumulation profiles of crab tissues, it can be concluded that metal-metal interactions and metabolic pathways play important roles in accumulation of specific metals. Metal concentrations in the sediment and seawater samples showed that the metal amounts and correlations in the crab

\section{References}

1. Alcorlo, P., Otero, M., Crehuet, M., Baltanás, A. \& Montes, C. 2006. The use of the red swamp crayfish (Procambarus clarkii, Girard) as indicator of the bioavailability of heavy metals in environmental monitoring in the River Guadiamar (SW, Spain). Science of the Total Environment, 366: 380-390.

2. Alexopoulos, E., McCrohan, C.R., Powell, J.J., Jugdaohsingh, R. \& White, K.N. 2003. Bioavailability and toxicity of freshly neutralized aluminium to the freshwater crayfish. Pacifastacus leniusculus.Archives of Environmental Contamination and Toxicology, 45(4): 509514.

3. Álvaroa, N.V., Neto, A.I., Coutoa, R.P., Azevedo, J.M.N. \& Rodrigues, A.S. 2016. Crabs tell the difference Relating trace metal content with land use and landscape attributes. Chemosphere, 144: 1377-1383.

4. Anderson, M.B., Preslan, J.E., Jolibois, L., Bollinger, J.E. \& George, W.J. 1997. Bioaccumulation of lead nitrate in red swamp crayfish (Procambarus clarkii). Journal of Hazardous Materials, 54:15-29.

5. Arya, S., Trivedi, J.N. \& Vachhrajani, K.D. 2014. Brachyuran crabs as a biomonitoring tool: a conceptual framework for chemical pollution assessment. International Research Journal of Environment Sciences, 3(1): 49-57.

6. Altas, L. \& Büyükgüngör, H. 2007. Heavy metal pollution in the Black Sea shore and offshore of Turkey. Environmental Geology, 52: 469-476.

7. Bervoets, L., Blust, R. \& Verheyen, R. 2001. Accumulation of metals in the tissues of three Spined Stickelback (Gastrosteus aculeatus) from natural fresh waters. Ecotoxicology and Environmental Safety, 48(2): 117-127.

8. Bochenek, I., Protasowicki, M. \& Brucka-Jastrzębska, E. 2008. Concentrations of $\mathrm{Cd}, \mathrm{Pb}, \mathrm{Zn}$, and $\mathrm{Cu}$ in roach Rutilus rutilus (L.) from the lower reaches of the Oder River, and their correlation with concentrations of heavy tissues did not reflect any environmental contamination. Very low metal concentrations were found in seawater samples. No correlation was found between metal concentrations in crab tissues and the sediment samples whereas significant correlations were determined among the crab tissues, meaning that metals present in the seawater and the sediment did not directly transform into accumulation in crab tissues. In order to examine the existing metal deposits in an aquatic environment and to have an understanding of the metal pollution, it is absolutely necessary to conduct analysis on the sediment. It was concluded that the sediment sample results reflected reality more than those of the seawater and the tissues analysed in this study.

\section{Acknowledgement}

This research was part of the $\mathrm{PhD}$ thesis of the Şeyda Fikirdeşici Ergen. I am grateful to Prof. Dr. Ahmet Altındağ (Ankara University, Turkey) for his valuable contributions.

metals in bottom sediments collected in the same area. Archives of Polish Fisheries, 16: 21-36.

9. Bresler, V., Abelson, A., Fishelson, L., Feldstein, T., Rosenfeld, M. \& Mokady, O. 2003. Marine molluscs in environmental monitoring. Helgoland Maine Research, 57 : 157-165.

10. Cannicci, S., Paula, J. \& Vannini, M. 1999. Activity pattern and spatial strategy in Pachygrapsus marmoratus (Decapoda: Grapsidae) from Mediterranean and Atlantic shores. Marine Biology, 133: 429-435.

11. Chagas, G.C., Brossi-Garcia, A.L., Menegário, A.A., Franchi, M., Carlos, A., Pião, S. \& Govone, J.S. 2009. Use of the Freshwater Crab Trichodactylus fluviatilis to Biomonitoring $\mathrm{Al}$ and $\mathrm{Mn}$ Contamination in River Water. HOLOS Environment, 9(2): 289-300.

12. Chua, A.C.G., Graham, R.M., Trinder, D. \& Olynyk, J.K. 2007. The regulation of cellular iron metabolism. Critical Reviews in Clinical Laboratory Sciences, 44: 413-459.

13. Cohen, C.K., Fox, T.C., Garvin, D.F. \& Kochian, L.V. 1998. The role of iron-deficiency stress responses in stimulating heavy-metal transport in plants. Plant Physiology, 116: 1063-1072.

14. Fikirdeşici Ergen, Ş., Üçüncü Tunca, E., Ozkan, A.D., Ölmez, T.T., Acaröz, E., Altındağ, A., Tekinay, T. \& Tunca, E. 2015. Interactions between metals accumulated in the narrow-clawed crayfish Astacus leptodactylus (Eschscholtz, 1823) in Dikilitaş Lake, Turkey. Chemistry Ecology, 31: 455-465.

15. Filazi, A., Baskaya, R., Kum, C. \& Hismiogullari, S.E. 2003. Metal concentrations in tissues of the Black Sea fish Mugil auratus from Sinop-Icliman, Turkey. Human \& Experimental Toxicology, 22: 85-87.

16. Guner, U. 2007. Freshwater crayfish Astacus leptodactylus (Eschscholtz, 1823) accumulates and depurates copper. Environmental Monitoring Assessment, 133(1-3): 365-369. 
17. Hung, T.C., Meng, P.J., Han, B.C., Chuang, A. \& Huang, C.C. 2001. Trace metals indifferent species of mollusca, water and sediments from Taiwan coastal area. Chemosphere, 44: 833-841.

18. Kramer, U., Talke, I.N. \& Hanikenne, M. 2007. Transition metal transport. FEBS Letters, 581: 2263-2272.

19. Kasmin, S. 2010. Enforcing ship-based marine pollution for cleaner sea in the strait of malacca. Environmental Asia, 3: 61-65.

20. Kır, I. \& Tumantozlu, H. 2012. Karacaören-II Baraj Gölü'ndeki su, sediment ve sazan (Cyprinus carpio) örneklerinde bazı ağır metal birikiminin incelenmesi. Ekoloji Dergisi, 21(82): 65-70.

21. Kurun, A., Balkıs, N., Erkan, M., Balkıs, H., Aksu, A. \& Ersan, M.S. 2010. Total metal levels in crayfish Astacus leptodactylus (Eschscholtz, 1823), and surface sediments in Lake Terkos, Turkey. Environmental Monitoring Assessment, 169(1-4): 385-395.

22. Makedonski, L., Peycheva, K. \& Stancheva, M. 2017. Determination of heavy metals in selected black sea fish species. Food Control, 72: 313-318.

23. Mendil, D. \& Uluözlü, Ö.D. 2007. Determination of trace metal levels in sediment and five fish species from lakes in Tokat, Turkey. Food Chemistry, 101: 739-745.

24. Menon, A.V., Chang, J. \& Kim, J. 2016. Mechanisms of divalent metal toxicity in affective disorders. Toxicology, 339: 58-72.

25. Moshtaghie, A.A. \& Taher, M. 1993. Aluminium interference with iron absorption by everted gut sac. Journal of Islamic Academy of Sciences, 6(4): 277-281.

26. Naji, A., Ismail, A., Kamrani, E. \& Sohrabi, T. 2014. Correlation of MT levels in livers and gills with heavy metals in wild tilapia (Oreochromis mossambicus) from the Klang River, Malaysia. Bulletin of Environmental Contamination and Toxicology, 1-6.

27. Nott, J.A. 1991. Cytology of pollutant metals in marine invertebrates: a review of micro-analytical application. Scanning microscopy, 5: 191-204.

28. Núñez-Nogueira, G., Fernández-Bringas, L., OrdianoFlores, A. \& Gómez-Ponce, A. 2013. Ni accumulation and regulation after experimental exposure to a $\mathrm{Cd}, \mathrm{Pb}$, and $\mathrm{Zn}$ mixture in the Pacific White Shrimp Penaeus vannamei. Water Air Soil Pollution, 224: 1644.

29. Oner, O. \& Celik, A. 2011. Investigation of Some Pollution Parameters in Water and Sediment Samples Collected From the Lower Gediz River Basin. Ekoloji, 20(78): 48-52.

30. Pandya, P.J. \& Vachharajani, K.D. 2011. Life Under Ecological Stress: An Estuarine Case Study. Pp. 427-436. In: Gupta, V.K \& Verma, A.K. (eds) Animal Diversity, Natural History and Conservation. Daya Publication House, New Delhi, India, xv + 480 pp.

31. Parsa, Y., Nabavi, S.S.M.B., Nabavi, S.N. \& Hosseini, M. 2014. Mercury Accumulation in Food Chain of Fish, Crab and Sea Bird from Arvand River. Journal of Marine Science: Research and Development, 4: 2.
32. Phillips, D.J.H. \& Rainbow, P.S. 1994. Biomonitoring of Trace Aquatic Contaminants, Chapman and Hall, London, $371 \mathrm{pp}$.

33. Pourang, N., Dennis, J.H. \& Ghourchian, H. 2005. Distribution of heavy metals in Penaeus Semisulcatus from Persian Gulf and possible role of metallothionein in their redistribution during storage. Environmental Monitoring Assessment, 100: 71-88.

34. Quarles, C.D., Jr., Marcus, R.K. \& Brumaghim, J.L. 2011. Competitive binding of $\mathrm{Fe}^{3+}, \mathrm{Cr}^{3+}$, and $\mathrm{Ni}^{2+}$ to transferrin. Journal of Biological Inorganic Chemistry, 16: 913-921.

35. Rainbow, P.S. 2007. Trace metal bioaccumulation: Models, metabolic availability and toxicity. Environment International, 33: 576-582.

36. Siddon, C.E. \& Witman J.D. 2004. Behavioral indirect interactions: Multiple predators effects and prey switching in the rocky subtidal. Ecology, 85: 2938-2945.

37. Soedarini, B., Klaver, L., Roessink, I., Widianarko, B., van Straalen, N.M. \& van Gestel, C.A.M. 2012. Copper kinetics and internal distribution in the marbled crayfish (Procambarus sp.). Chemosphere, 87(4): 333-338.

38. Trivedi, J.N., Gadhavi, M.K. \& Vachhrajani, K.D. 2012. Diversity and habitat preference of brachyuran crabs in Gulf of Kutch, Gujarat, India. Arthropods, 1: 13-23.

39. Tunca, E., Üçüncü, E., Kurtuluş, B., Ozkan, A.D. \& Atasagun, S. 2013a. Accumulation trends of metals and a metalloid in the freshwater crayfish Astacus leptodactylus from Lake Yeniçağa (Turkey). Chemistry and Ecology, 29(8): 754-769.

40. Tunca, E., Ucuncu, E., Ozkan, A.D., Ergul-Ulger, Z., Cansizoğlu, A.E. \& Tekinay, T. 2013b. Differences in the accumulation and distribution profile of heavy metals and metalloid between male and female crayfish (Astacus leptodactylus). Bulletin of Environmental Contamination and Toxicology, 90(5): 570-577.

41. Tüzen M. 2003. Determination of heavy metals in fish samples of the middle Black Sea (Turkey) by graphite furnace atomic absorption spectrometry. Food Chemistry, 80: 119-123.

42. Ullah, A., Heng, S, Munis, M.F.H., Fahad, S. \& Yang, X. 2015. Phytoremediation of heavy metals assisted by plant growth promoting (PGP) bacteria: A review. Environmental and Experimental Botany, 117: 28-40.

43. Walton, R.C., McCrohan, C.R., Livens, F. \& White, K.N. 2010. Trophic transfer of aluminium through an aquatic grazer-omnivore food chain. Aquatic Toxicology, 99: 93-99.

44. Woodburn, K., Walton, R., McCrohan, C. \& White, K. 2011. Accumulation and toxicity of aluminiumcontaminated food in the freshwater crayfish, Pacifastacus leniusculus. Aquatic Toxicology, 105: 535-542.

45. Yildiz, N. \& Yener, G. 2010. Dating of the sediment accumulation rate, radioactive and heavy metal pollution in the Van Lake. Ekoloji, 19(77): 8. 
